\title{
Santa María de la Antigua del Darién: the Aftermath of Colonial Settlement
}

\author{
Alberto Sarcina
}

Chance played a great role in the entire first part of the Iberian conquest of the continent nowadays known as America. Among the many plays of destiny, the first and crucial one was that Columbus by chance (and by mistake of calculations) found the Antilles, while he was sailing towards Cathay and Cipango. The encounter with what was perceived more and more clearly as a new land of considerable dimensions confronted the Spanish rulers with a totally new situation, which they began to face with strategies that were sometimes contradictory, but always following from the political and military experience they had gained in the phase of European expansion and consolidation. In Late Medieval Europe, the concept of empire was linked to an idealized line of succession dating back to the Holy Roman Empire. However, it was precisely the fall of the Byzantine or Eastern Roman Empire, with the conquest of Constantinople by Mehmed II in 1453, that elicited the need to open new roads from the West to the Indies.

The kings of Spain were inspired by the Roman imperial model when they had to face the abyss of the unknown. The governors and governances of the New World colonies were the equivalents of the Roman governors in the imperial provinces. Likewise, the main base of territorial domination was the founding of cities, which acted as military as well as symbolic bastions of the nascent Spanish imperial expansion. The cities of the new colonies were built with inspiration in the ideal model of the orthogonal Greek-Roman city, in a new Renaissance version that placed the cathedral church and the Plaza Mayor at the center of the urban grid. However, the models of Spanish imperial domination and the ideal plans of the cities to be founded in the New World, so clearly conceived in theory, were reshaped and transformed when confronted with the reality of the new lands, that is, with the indigenous peoples who inhabited it and with the environment so different from that of Europe.

Santa María de la Antigua del Darién is a paradigmatic case since it is the first Castilian city founded on the American continent. We do not know the 
plan of this city, but we have the historical record on how it was planned to be built. We possess the King's instructions given to the governor Pedro Arias de Ávila on how and where to found new cities. Also, we possess some detailed information about the incredible campaign financed by the Spanish Crown that consisted of a fleet of twenty ships loaded with all the elements supposed to be essential in a sixteenth-century Castilian city and with two thousand passengers representative of all kinds of trades, from peasants to the bishop. These documents are the testimony of the ideal of a city that the Spanish wished to build in the middle of an unknown continent. The ambitious plans failed, and the ideal had to be molded and transformed into something probably less sublime, but surely novel.

In 1510, an armed and desperate group of Spaniards landed on the banks of the Darién River, a few kilometers inland from the western side of the Gulf of Urabá, in what is today Colombia. Over the past six months, the Spaniards had resisted the attacks of the indigenous Urabaes in their fort of San Sebastián de Urabá, on the opposite (eastern) shore of the Gulf. They had suffered great losses and of the three hundred men that had arrived, only some fifty had remained. The rest had died of malnutrition, illnesses, or infections caused by indigenous arrows poisoned with curare (Oviedo, Historia, Vol. 2, Book XXVII, Chap. IV). The purpose of the Spaniards had been the founding of a settlement that was intended to be the first component and future capital of the new province of Nueva Andalucía, under the direction of governor Alonso de Ojeda. Ojeda himself, meanwhile, had been lost at sea in an attempt to reach Hispaniola and collect the reinforcements that had been gathered there by lieutenant-captain Martín Fernández de Enciso. Now, having reached the Darién River, the survivors' only goal was to stay alive.

What they found $6 \mathrm{~km}$ upriver from the coast was a Cueva-speaking indigenous village called Darién, like the river that passed alongside it (Oviedo, Historia, Vol. 2, Book XxVII, Chap. IV), and some five hundred indigenous men ready to defend their land, commanded by a cacique named Cemaco. The Spanish eventually managed to win the conflict and they settled in the village, which they named Santa María de la Antigua del Darién, in honor of the image of the Virgin that is kept in the Cathedral of Seville, a primary site of devotion for seafarers heading for the West Indies. The settlement, arisen more by reason of hunger and chance than through planning, soon became the first outpost of the conquest - the first Spanish enclave in an indigenous universe. With the discovery of the South Seas in 1513 and the subsequent possibility of the Spanish to continue on course towards the East Indies, as well as upon receiving the title of city and diocese, Santa María de la Antigua del Darién became the center of the new empire (or rather the hopes of a new empire) 
for the Spanish. This is the only moment in (modern) history in which western Urabá was the center of any state interest.

Today, the area where Santa María de la Antigua del Darién was founded lies in the north of the Chocó Department of Colombia, some five hundred meters from the Tanela River, a tributary of the Atrato by way of the Cienaga de Marriaga. This area of low hills belonging to the foothills of the Serranía del Darién mountain range is now characterized by extensive cattle ranches. These ranches are evidence of territorial occupation by a few large landowners, and in some cases represent the direct or indirect outcome of the conflicts and violence in this part of the country between the end of the 199os and the first years of the current century (Grupo de Memoria Histórica 2013). Colombian state authority is minimal here, and in fact the area is controlled by armed groups named BaCrim ('Criminal Bands'), which represent a direct continuation of the paramilitary groups that preceded them. This situation of lack of state control essentially began with the abandonment of Santa María de la Antigua.

In 2013, the Colombian Ministry of Culture and the Colombian Institute of Anthropology and History initiated an archaeological project in this area under the direction of the author. The goal of the project was to identify, delimit, and scientifically study the site of the first Spanish city founded on the American continent. This project, which resulted in the creation of an archaeological park and the construction of a Patrimonial House, has been the first step towards state presence in the area, based on a cultural approach and one of social inclusion.

In the present chapter, I wish to reflect on the relationship between the indigenous population that inhabited the city of Santa María (or, rather, frequented it) and the conquistadores during and after the city's existence, using chronicles and archaeological data recovered during five years of investigations (2013-2017). Firstly, a spatial proposal of the city will be made as maps and detailed written descriptions are lacking. Next, I shall analyze some data from the stratigraphic excavations of 2015 and, subsequently, the final moments of the city by comparing documentary sources and archaeological data. Finally, the years immediately following the abandonment of the city, on which there is practically no evidence, will be reflected upon.

\section{Appearance of the City: an Approach to the Nonexistent Map of Santa María de la Antigua del Darién}

In 1514, when Pedro Arias de Ávila, the new governor appointed by the Spanish Crown, arrived at Santa María de la Antigua directly from Seville, together with 
more than two thousand people, he was greeted by Vasco Núñez de Balboa, who received him

... with five hundred and fifteen men who were living there and had built more than one hundred houses or buhíos [bohios: indigenous houses]: and the population was very kind, and a beautiful river passed alongside the houses of the city, of very good water and with many good fish. This is the river of Darién, and not the one that in book XXVII the bachelor Vadillo called the river of Darién, and this one comes from the eastern part, and the one that he mentions is a branch of the river Sanct Johan, that enters the posterior part of the Gulf of Urabá, as history has already said. ...

There were among those first settlers more than one thousand five hundred indigenous men and women naborías [servants] who served the Christians in their haciendas and homes.

oviedo, Historia, Vol. 3, Book XXIX, Chap. VIII

Gonzalo Fernández de Oviedo is the principal source for the reconstruction of Santa María de la Antigua's history. As an observer of the founding and later mayor of the city, he offers relevant information about the first Spanish fort, which was established within the indigenous settlement conquered in 1510. When Fernández de Oviedo arrived in 1514 with the fleet of Pedrarias Dávila, approximately two thousand people lived in Darién: five hundred Spaniards and one thousand five hundred indigenous peoples; the latter being servants (naborías) of the first. The town had more than one hundred houses and the river ran alongside it. However, another chronicler, named Pascual de Andagoya, says: "Effectively, la Antigua, formed by some two hundred houses of indigenous style, and inhabited by the Spaniards from Balboa and their indigenous servants, could not comfortably accommodate the 1,500 new inhabitants who arrived with Pedrarias" (Andagoya, 1986). Obviously, here we face our first problem: were there one hundred or two hundred houses? Whom do we believe, Oviedo or Andagoya? Both arrived there at the same time in the armada of Pedrarias Dávila, so that both are direct, and theoretically, reliable witnesses. Nonetheless, it is hard to imagine that two thousand people would fit in the one hundred houses mentioned by Oviedo, unless he referred to only Spanish houses.

The issue leads to the question how the first Spanish cities founded on the new continent were spatially organized? In this respect the instructions King Ferdinand II (the Catholic) gave to Pedro Arias de Ávila on August 4, 1513 are a frequently cited and studied source. Among instructions and recommendations about various issues, they address the new foundations and their layout: 
... you will distribute the solares [plots, pieces of land] of the place to build houses, and these are to be distributed according to the qualities of the people and are to be orderly from the beginning. Once the solares are made, the town is to look ordered: in the place destined for the plaza, where the church is to be, and by the orderliness of the streets. Since in the places that are newly built and where there is orderliness from the beginning, without any work or cost they remain orderly, and the others never become orderly [by themselves]. ... The distribution is to be such, that everyone is to receive part of the good [land], part of the mediocre [land], and part of the less good [land]. ${ }^{1}$

The King specified the dimensions of the farmland and the solares in a subsequent royal decree on August 9, stating that the solares would be $100 \times 80$ paces, some $56 \times 44.8 \mathrm{~m}^{2}$ According to Aprile-Gniset (1991, 186-215), originally the construction of the colonial American cities was not developed following the regulations established by the Crown. Indeed, many of these cities were developed prior to the Instrucciones y reglas para poblar issued between 1523 and 1529, and some, as Santa María de la Antigua, were constructed even prior to the Instrucciones a Pedrarias Dávila (1513). Manzanas (blocks), city blocks, and squares, according to the author, were developed in a quadrangular rather than rectangular shape as was planned. A city block, consisting of four manzanas, would then measure $85 \times 95 \mathrm{~m}$ (Aprile-Gniset 1991, 202), as the Plaza Mayor. The sides of the solares would measure between 42.5 and $47.5 \mathrm{~m}$. Aprile-Gniset (1991, 198), after analyzing twenty centers founded by the Spanish in the first phases of conquest, summarizes their layouts as three different shapes of an orthogonal "grid": (1) a completely orthogonal reticle; (2) atypical cases formed by the seascape or fluvial conditions; and (3) non-conventional layouts of "spontaneous character." Neither Santo Domingo nor Panamá la Vieja seem to have had a strict grid. Instead, it seems that the foundations had to be adapted and their layout molded following the topography of the chosen places. According to Panama's street plan of 1586 by Juan Bautista Antonelli, the city blocks do not seem to have had a fixed measure and, as in Santo Domingo, there existed a certain polycentrism since the city had several squares besides the Plaza Mayor, and the Casas Reales were not on it (Tejeira Davis 1996, 57). Additionally, both cities were far from having manzanas of the dimensions

1 Published in Manuel Serrano y Sanz, Origenes de la dominación española en América, Madrid, Libreria General de Victoriano Suarez, 1918, vol. I, CCLXXIX-CCLXXXVI.

2 Following Tejeira Davis $(1996,45)$, in the times of Pedrarias one pace corresponded to 2 pies (Castillian feet $=$ c. $28 \mathrm{~cm}$ ). 
suggested by the Crown $(100.8 \times 100.8 \mathrm{~m})$ : they had manzanas of much smaller size, especially Panamá la Vieja.

The layout of Santa María de la Antigua del Darién must have been even more atypical. It has to be considered in relation to cities founded next to a river, such as Mompox, since as Oviedo mentions, the Darién River ran alongside the houses. But there is another important characteristic: the first fort was founded within the indigenous settlement, using its houses and architecture. In fact, the Spaniards arriving with Balboa and Enciso in 1510, beat the indigenous peoples commanded by the cacique Cemaco, entered the town "and there these people fortified themselves, and so they settled" (Oviedo, Historia, Vol. 2, Book XVII, Chap. IV). Of course, the succeeding settlement must have been different with respect to the indigenous town, because after the conquest of the town by Balboa and Enciso (and before the arrival of Pedrarias),

... the captain, Rodrigo de Colmenares, had gone with a vessel, and landed at Gaira, below Sancta Marta, and the Carib Indians killed more than thirty of his men because of not being cautious; and from there he went to the Darién with those who remained, who were more than a hundred. Then the Captain Cristóbal Serrano went and took with him more than two hundred people, among which there were one hundred and fifty fighting men, and in other vessels others went. So, that small town was more populated. With which the first conquistadores, before Colmenares and Serrano went, were joined by those that remained from the armada of Captain Diego de Nicuesa, as has been said ....

oviedo, Historia, Vol. 3, Book Xxix, Chap. II

The original town surely expanded, and probably partially changed its layout. However, it must have preserved most of its original orientation, especially the area where the first chapel was founded (Anglería 1989, 104), at the house of the defeated cacique himself.

Five years of archaeological research have shown that the region where the city of Santa María de la Antigua del Darién developed consists of two different and adjacent sites, the first corresponding to the indigenous town of Darién conquered in 1510, and the second to the town founded by governor Pedro Arias de Ávila in 1514 (Sarcina 2017). In order to distinguish them archaeologically, these sites have been named Darién and Santa María de la Antigua (Figure 8.1). The archeological evidence behind this distinction consists of a larger presence of Spanish material among the finds encountered during the test pit survey at the second site (Sarcina 2017) and the distinct stratigraphic sequences of both sites. The stratigraphic excavations of 2014 and 2015 at the site of Santa María de la Antigua showed post-abandonment, abandonment 


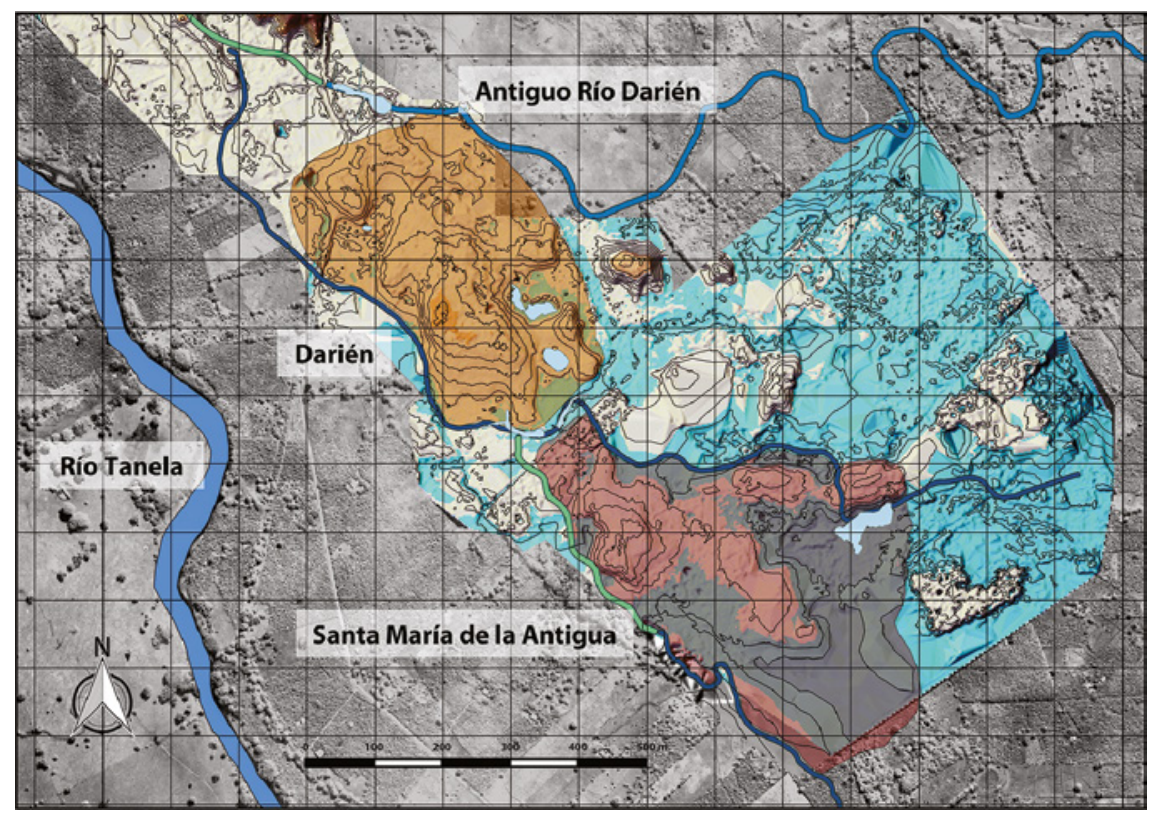

Figure 8.1 The area of Santa María de la Antigua del Darién, formed by its two sections, Darién and Santa María de la Antigua, Colombia, according to the results of the 2013 test pit survey, and the 2014-2016 stratigraphic excavations. To the left, the current Tanela River, and next to the city, the reconstruction of the old course of the Darién River and its two branches

and colonial-contact phases in the stratigraphy. Below these phases, there is no evidence of human occupation. In Darién, to the contrary, there is a relevant pre-Hispanic phase, characterized by an occupational model of house and garden, which is currently being dated (Sarcina 2018).

Another matter that was clarified is the old course of the Tanela River (Old Darién) that today runs $500 \mathrm{~m}$ from the archaeological sites. As we can see in the reconstruction in Figure 8.1, we now know that a branch of the river ran immediately to the city's west and another one cut the city in half, while the main course ran towards the northeast of the ancient indigenous town.

\section{An Indigenous Naboría House in Darién}

The 2015 investigations mainly consisted of the excavation of a $23 \times 23 \mathrm{~m}$ excavation unit (excavation unit F) in the area of Darién. Satellite image analysis suggested the existence of two rectangular anomalies, one within another, probably related to a solar (or manzana) dating from the Spanish founding. 
This hypothesis was proven by the results of the archaeological investigations that saw a spatial distribution of European findings concentrated in the portion of the excavation unit corresponding to these anomalies (Sarcina 2018).

If these anomalies actually do correspond to a solar or manzana from the old city, they would have dimensions of approximately $39 \times 54 \mathrm{~m}\left(2106 \mathrm{~m}^{2}\right)$ in the case of the "inner" and darker anomaly and of $48 \times 63 \mathrm{~m}\left(3024 \mathrm{~m}^{2}\right)$, in the case of the lighter one. This land would have been adjacent to the old branch of the Darién River, and not much deviant from the rules on solares dictated by the Crown. Nonetheless, when comparing the situation to the plan of Panamá la Vieja, and observing how in these first foundations the solares and manzanas had dimensions much smaller than the ones dictated by the royal rules, it is likely that in this case it could have been a manzana.

The area of dispersion of the archaeological material at Darién is about 12.3 ha. This would give us the space (excluding streets and possible squares) for 58 manzanas in the first case and 40 manzanas in the latter; that is 224 or 160 solares. This comes closer to Andagoya's assertions, although these solares of small dimensions would surely be distributed according to the importance of the vecino (resident) or the institution. The Cathedral, for example, had four solares as did the Monastery of San Francisco, while Balboa had two solares and two houses. The excavation unit F investigations in 2015, which yielded part of these possible solares, revealed the presence of a small structure inhabited by indigenous peoples, from which we found postholes, two hearths, and a trash midden. All of the material encountered in this space in the northeastern part of the excavation unit was of indigenous manufacture. European material appeared abruptly at the southwestern limit of the excavation unit (Figure 8.2). The geophysical investigations, which were carried out in the area immediately southwest of the excavation unit, showed a rectangular anomaly. This allows us to hypothesize that what was found may have been the house of an indigenous family of naborías (servants) in the service of a Spanish family whose house (the anomaly detected) was erected on the adjacent solar to the southwest (Sarcina 2018). This would imply a physical co-presence of structures and people, including Spaniards and indigenous peoples, at least in the part of the city that was conquered by the Spaniards in 1510 .

The trash midden of the indigenous house, excavated in 2015 and 2016, appeared to had been formed inside an old canal running northeast towards a shoal where today there is a wetland. Thus, it is possible that this midden had a drainage function as well. Among the large pottery sample recovered from the midden, one indigenous ceramic fragment stands out. This distinct piece was painted externally with a European-inspired apparently vegetal decorative motif (Figure 8.3). What is interesting about this discovery is that it was found in an indigenous context that contained only indigenous-made material, even while situated adjacent to a possible solar occupied by Spaniards. This piece, 


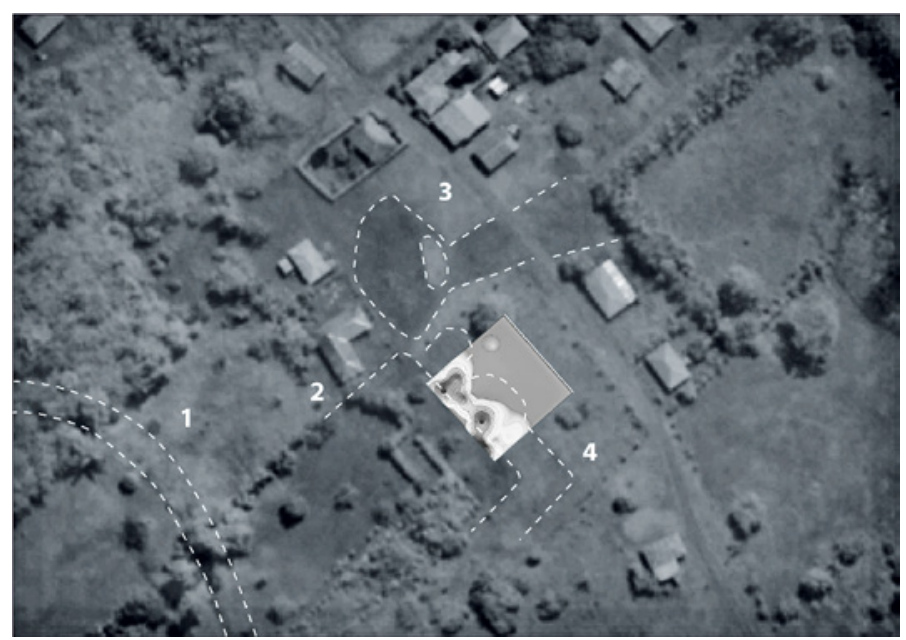

FIGURE 8.2 Rectangular anomalies at the site of Darién (4 and 2), and another anomaly identified in the area. To the left, the old course of one of the branches of the Darién River. In white, the area of excavation unit $\mathrm{F}$ and the density of Spanish findings at the site, focused in the southwestern part

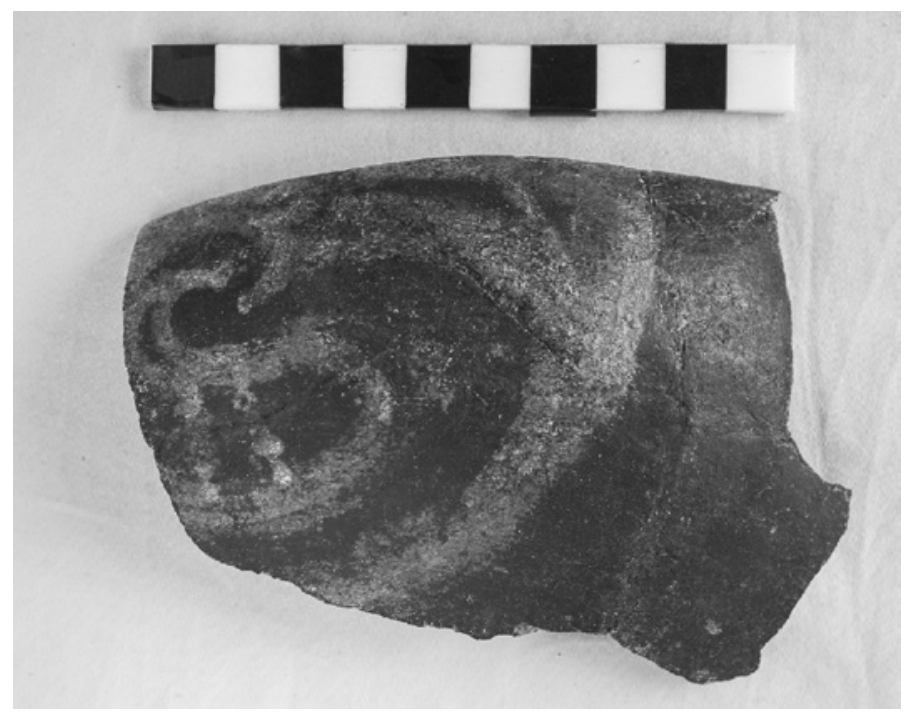

FIGURE 8.3 Indigenous-made pottery with vegetal motif of Spanish inspiration, found in the midden of excavation unit F, Darién

ultimately, represents the fruit of experiments by local potters that were inspired by the decoration of imported ceramics belonging to the invaders. This is an interesting case of syncretism where the change in taste of the indigenous peoples is evidenced, and where the naborias themselves reproduced the ornamental forms of their masters. 
After the arrival of governor Pedro Arias de Ávila and more than two thousand men and women in 1514, the Spaniards had to establish a new part of the city to the southeastern end of the first foundation, following the course of the Darién River branch (Sarcina 2018). The area of dispersion of the archaeological material in this second foundation is about 18 ha, corresponding to 85 or 59 manzanas, measured according to the biggest or smallest of the anomalies studied in 2015. Santa María, formed by these two entities, would officially have the status of city in 1515, with a coat of arms and episcopal see. Nevertheless, it would be abandoned for reasons that go beyond the scope of this chapter in 1524. Its population would disperse mainly to Panamá, Acla and Nombre de Dios, which were settlements founded (or refounded as in the case of Nombre de Dios) by Pedrarias Dávila himself and his captains between 1515 and 1519 .

Once again thanks to Gonzalo Fernández de Oviedo, we have a description of the last days of Santa María de la Antigua del Darién. He speaks of how between 1521 and 1523 the population gradually diminished, "[...] every day the vecinos left, because the governor promised and gave them indios de repartimiento [the natives given to an encomendero] and other advantages to those that left the city" (Oviedo, Historia, Vol. 3, Book xxIx, Chap. XIV). In his military action against cacique Bea, Oviedo himself faced troubles gathering enough armed people, "[...] because in the city there were few people, since every day we were less, because the governor, to all those who went where he was, would flatter them and give them repartimientos there, and they would not return to Darién [...]" (Oviedo, Historia, Vol. 3, Book XxIX, Chap. Xv). The description of the last days is quite dramatic:

Two to three months later, Darién was depopulated, in the month of September in the year fifteen twenty-four. And once the vecinos of the city left, among those who remained was Diego Rivero, who as was mentioned in Chapter II of Book XXv, went or rebelled against the governor Diego de Nicuesa with the vessel, and left him lost on the island of Escudo. And his own indios, of this Diego de Rivero, together with others who joined them, killed him. And they killed one of his sons, who was from eight to ten years old, they hanged him from the rafter of his own hut, and they killed the mother of this child and another three or four ill Christians, and they burned down most of that city, and among the other houses, mine ....

OVIEDo, HistoriA, Vol. 3, Book XXIX, Chap. XXII 
However, Oviedo did not witness these occurrences since he departed to Spain on July 3, 1523. Upon reaching Spain, he complained before the court of the governor's behavior, who after moving the episcopal see and all major political positions to Panamá, continued to promote a policy of depopulating Santa María in favor of new foundations. How much truth would there then be in his relation?

The stratigraphic excavations of 2014 through 2016 allowed us to identify strata with signs of burning in almost all levels belonging to the contact period. In 2014, the small excavation unit $\mathrm{D}(2 \times 2 \mathrm{~m})$, excavated in an area of the Darién site adjacent to that of Santa María de la Antigua, yielded a dirt floor with evident traces of burning and parts of a moved cobble pavement. In excavation unit F, excavated in the central part of the Darién site in $2015,76 \%$ of the postholes showed signs of burning. There were also signs of burning related to the rafters and other parts of the house (Sarcina 2018). Besides, the portion of the excavation unit with the greatest presence of Spanish material yielded things that apparently were broken in situ, such as an Isabela Polychrome majolica plate, a pair of scissors, and a sword blade that along with its hilt was shattered into four pieces. Hypothetically, this appears to be a site that went through an attack and was burned down intentionally. In 2016, excavation unit $\mathrm{H}$, which is still under excavation at the site of Santa María de la Antigua, also presented clear evidence of burning in the levels corresponding to the contact period. There are three stains of rectangular shape, measuring $6.30 \times 3.30 \mathrm{~m}, 4.30 \times 3.10$ $\mathrm{m}$, and $4.00 \times 2.90 \mathrm{~m}$, and (as far as the current excavation has gone) a fourth stain from which only a corner has been identified, also with clear evidence of burning (Figure 8.4). All of them have the same SW-NE orientation. At the moment, this evidence has been interpreted as the burned floors of small wooden structures, probably related to each other. Furthermore, virtually intact Spanish material, left in situ, has been found at the site, in particular, a botija (olive jar) and three glazed vials. All this evidence may belong to different fires at different moments throughout the existence of the city, but at least in the cases of excavation units $\mathrm{F}$ and $\mathrm{H}$, we would hardly find material of common use abandoned or broken at the site. At the moment, the most consistent interpretation seems to be a confirmation of Oviedo's words.

Not much is known about what happened in the area of Santa María de la Antigua del Darién after it was abandoned in 1524 . The sources reveal very little, although there are some interesting clues, as will be seen in the following 


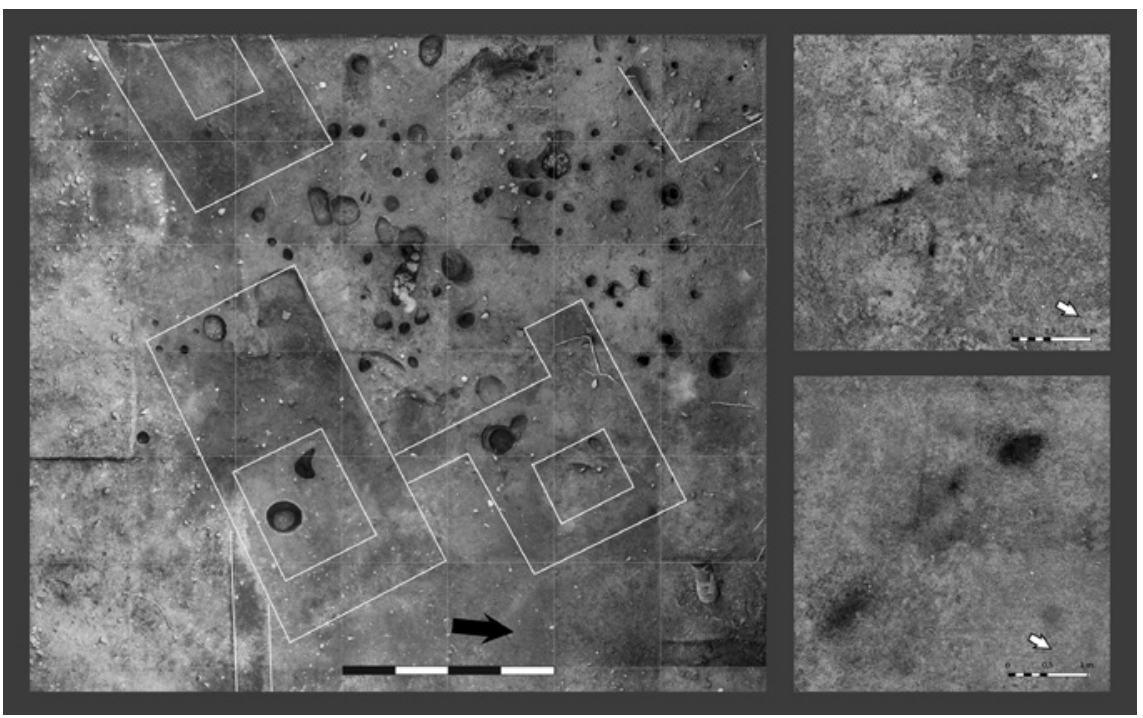

FIgURE 8.4 Santa María de la Antigua. On the left, four rectangular stains (in white lines) possibly related to burned cabin floors in excavation unit $\mathrm{H}$ (2016). On the right, signs of burning related to the rafters in excavation unit $\mathrm{F}$ (2015)

paragraph. With regard to the results of the stratigraphic excavations of the past few years, the stratigraphy related to this phase is very poor, and there is no evidence of a stable reoccupation of the site until modern times. ${ }^{3}$

However, there is clear evidence that this area was being frequented immediately following the Spanish abandonment. The principal indications of these visits are a series of offering activities which we have termed "ritual caches." These are, stratigraphically speaking, cuts made into the layers immediately above the phase of contact, that is, at a moment soon after abandonment. These cuts, found in excavation units $\mathrm{A}$ and $\mathrm{H}$ at the site of Santa María de la Antigua, were made in order to deposit offerings. Excavation unit A (2014) yielded two floors of cobbles and packed earth, possibly related to two internal patios of a large wooden construction, which, in turn, prompted the discovery of the "ritual caches," found some two meters north of the Spanish

3 Today there is a small village, called Santuario, that was built nearly exactly on top of the indigenous settlement of Darién (and the first Spanish foundation of 1510) in the 1980s. It is inhabited by colonists originating mostly in the coastal region of Cordoba. 
floors (Sarcina 2014; Rivera 2014). Three groups of offerings were found: the first constituted five small vessels of $8-10 \mathrm{~cm}$ in height, while the second contained four vessels with similar dimensions, a small $5 \times 3 \mathrm{~cm}$ axe, and two spindle whorls (Figure 8.5, left). The third offering held a semi-cylindrical mano of $30 \mathrm{~cm}$ in length. The vessels were roughly manufactured, many of them with irregular rims. To the contrary, the small axe and the mano were excellently made. In excavation unit $\mathrm{H}$ (2016), excavated $65 \mathrm{~m}$ north of excavation unit $\mathrm{A}$, two more caches were found. One of these consisted of a large vessel with inside a small axe $(4.5 \times 3 \mathrm{~cm})$. The second cache (UE 77$)$ discovered a few meters away, was composed of a large globular container, which held a medium-sized vessel and a small other one, $9 \mathrm{~cm}$ high, with zoomorphic decoration (Figure 8.5 , right).

If, as is suggested by the archaeological investigations, there was actually no true reoccupation of the site, what is the meaning of these offerings? The Cuevas did not return to the site where they lived previously, because of fear or because the physical and metaphysical environment had become somehow "contaminated" by too many years of violence and slavery? In this case the offerings, these "ritual caches," perhaps had the function of purifying the area from all the negative things that had occurred in the previous fifteen years, restoring some form of balance to this space. Hopefully, future (archaeological and ethnoarchaeological) investigations will help us resolve this enigma.

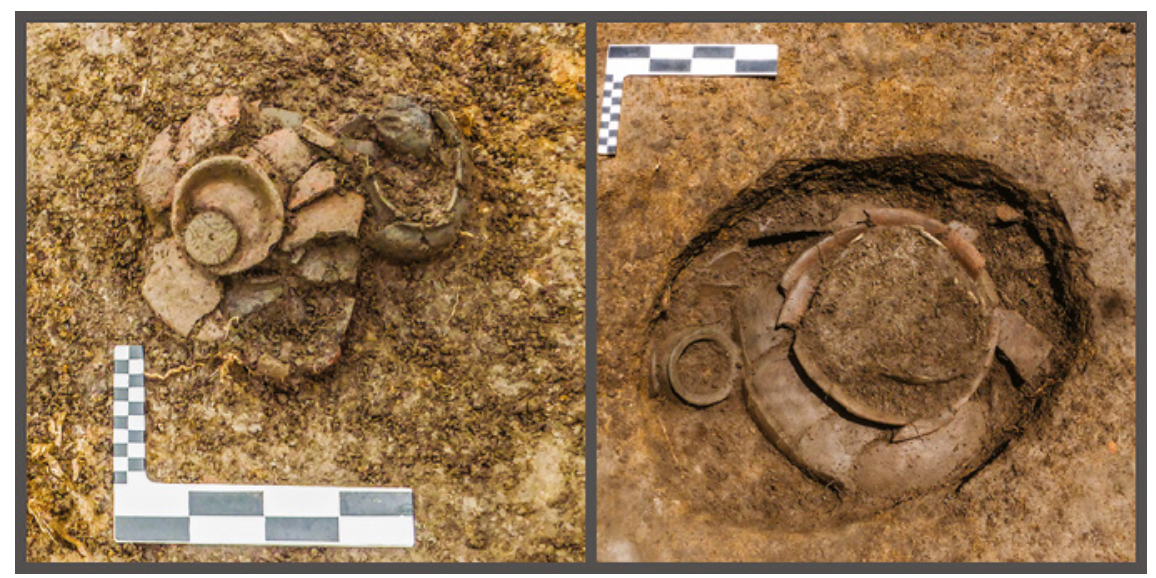

FIGURE 8.5 Ritual caches in the post-abandonment levels of Santa María de la Antigua. To the right, UE 77 from excavation unit $\mathrm{H} 2016$, and, to the left, UE $30-31$ from excavation unit A 2014 
In the Culata, of the gulf of Urabá, it was a blessing to discover certain rescate [barter] and engagement with the indios from there, in a very good manner. That is, a certain navy that stations there, and with the royal official of Your Majesty in this land, among the indios he took, brought an indigenous woman who said to be of the cacique Cemaco, who is the one who was of Darién, who is there settled. And with her went a vecino from Acla, servant and steward of licenciado Corral, to whom the said cacique was given in encomiendo. The vecino went with her and with other persons he had from said cacique, and they spoke to him and his indios, and they gave him six hundred or seven hundred pesos of gold, and he [the cacique] and other caciques from that Culata remained very peaceful.

Carta del licenciado Espinosa, Panamá, August 15, 1532, doc. 392 in FRIEDE, 1955196o, 286

This fragment from the letter of licenciado Espinosa to the King, written in Panama seven years after the abandonment and burning of Santa María de la Antigua del Darién, offers us some important insights. First of all, it is pertinent to note that the memory of the cacique Cemaco still lingered, the same cacique who had to receive the group of Spaniards headed by Nuñez de Balboa and Fernández de Enciso in 1510, 22 years previously. It is possible that what is being discussed here is Cemaco's family, and that the indigenous woman was part of this group. It is also mentioned that this group was related to the first inhabitants of Darién, which "is there settled," meaning in the zone of $\mathrm{La} \mathrm{Cu}$ lata (the part to the south of the Gulf).

The "vecino from Acla" is Julian Gutiérrez, who had lived in Santa María de la Antigua in the service of bachelor Diego del Corral (Oviedo, Historia, Vol. 3, Book XXIX, Chap. XIX). The latter was one of the first settlers of the city, who arrived before the armada of Pedrarias, with Rodrigo de Colmenares. It is worthwhile to pause a moment on the figure of bachelor Del Corral, one of the most powerful and influential vecinos of Santa María, who owned a house in the principal part of the city and an estancia (country house) half a league outside the city (Oviedo, ibid., Chap. Xx). Espinosa tells us in this letter, that the cacique Cemaco and his people were given in encomienda to him, although in Oviedo we read that it was the cacique Corobarí (Oviedo, ibid., Chap. Xv), a detail confirmed by the words of governor De la Gama (Friede, doc. 499, 41). From the pages of Oviedo we can infer that in the houses of the bachelor Del Corral there was a level of familiarity with some indigenous families: the 
cacique Bea "was a close relative of one indigenous woman that the bachelor had as a concubine, with whom he had children" (Oviedo, ibid.); the cacique Corobarí had in the house of the bachelor "his mother, wife, and children" (Oviedo, ibid.); and "there was understanding between them, and they spoke in his estancia outside the city" (Oviedo, ibid., Chap. xx). Thus, Del Corral had close relations with these caciques, also in part because of his concubine/wife Elvira and her son Perico, as well as their relatives. So much so, that in 1521 the bachelor tried detaining an expedition organized by Fernández de Oviedo (at the time the mayor of the city) in order to bring to submission the caciques Bea, Corobarí, and Guaturo who had rebelled. He was then detained and sent to Spain, charged with publicly having an indigenous concubine (Oviedo, ibid., Chap. XV and XVI).

A very interesting fragment of the history of the first phase of the colonization is the story of Julian Gutiérrez and the india Isabel. She was a lengua or translator, related to some of the principal caciques of the lower Urabá, and later became wife of the same Gutiérrez. The narrative is found largely in the collection of the Patronato at the General Archive of the Indies in Seville, and the great majority of the folios have been transcribed in the "Documentos inéditos para la historia de Colombia," edited by Juan Friede (Friede, 1955-1960). In 1532, the territory that belonged to the governorate of Castilla del Oro was divided into various new governorates and provinces: Panamá, Santa Marta (from 1524), Nicaragua (from 1528), and Cartagena (precisely from 1532). The boundary line between the governorates of Panamá and Cartagena was the Gulf of Urabá, and the San Juan River (today the Atrato). There, however, was no clear agreement and this would lead the governorates to first confront each other legally and later (around 1534-1535) physically and militarily. This eventually resulted in Cartagena and its governor Pedro de Heredia emerging as winners.

At the time the letter by licenciado Espinosa was written, the new governor of Panamá, the licenciado Antonio de la Gama, decided to change the politics with respect to the indigenous groups that still remained in the lower part of the Gulf of Urabá. This change, reminiscent of the policy of Nuñez de Balboa, consisted of more peaceful relations with the natives based on barter and exchange. It is possible that this alteration arose as a result of the political situation created by the adjacent formation of a new and powerful governorate. The last violent "entry" of pillaging and plundering, during which the Spanish devastated various indigenous villages and took numerous prisoners, was undertaken by the royal official Miguel Juan de Ribas and his captain Esteban Milanés, who died during the expedition (Friede, doc. 393, 287-296). The decision of the governor was to return the prisoners to their respective settlements and 
make peace with all of the caciques of "la Culata del Urabá." This was done by using Julián Guitiérrez, a man who already had a relationship with an indigenous woman, ${ }^{4}$ who was a relative of some of the caciques of the area. Gutiérrez was raised in Santa María de la Antigua in the house of bachelor Del Corral, in an environment where there were many relations with local caciques and their families. On August 25, 1532 the following statement was written:

The licenciado Mr. Antonio de la Gama, governor of this Kingdom of Castilla del Oro for His Majesty, commands that any person who has an indigenous man or woman from among those brought by the armada of the royal official Miguel Juan de Ribas, of which Esteban Milanes, deceased, was the captain, would come and show them to him in the next three days, with a penalty of ten pesos of gold for each person who does not show up.

FRIEDE, doc. 393,292

This change in policy is quite impressive, especially when compared with the customs in force during the government of Pedro Arias de Ávila. In fact, it is probably the first time that we can observe the restitution of indigenous slaves to their lands. The peace with these groups, which evidently was still kept in the territory close to where Santa María de la Antigua once stood, had necessarily to result in new behaviors. Without doubt, this was imperative because this specific territory was in dispute between the governors and having the indigenous peoples allied was a point of strength. This part of the Gulf was frequented by various groups of Spaniards, some of whom probably belonged to the people of Pedro de Heredia, since Julián Gutiérrez asked the governor for a letter to give to the caciques: "so that if any vessel or people arrive there showing interest, do not hurt the said indios" (Friede, doc. 393, 295). The governor in effect wrote the letter, directed to

4 According to a letter sent by governor De la Gama from Panamá to the King on May 15, 1533, Isabel Corral was a "principal indigenous woman, very understood and a good Christian. Since a child, she had been raised with the said Julian Gutiérrez in the house of the said licenciado (Del Corral) who was in charge of his hacienda and house. She is the relative of the principal caciques and indios with whom friendships were settled, and this indigenous woman was the translator in the peace accords, and the principal part in their occurring. And having seen this, I spoke to the said Julian Gutiérrez and begged him that he marry her, because by doing this, apart from serving Our Lord and His Majesty, the good work she had done in the peacemaking would be rewarded" (Friede, doc. 499, 42). 
... all the captains, masters, pilots, majors, and whichever persons from whatever vessel, caravel, brigantine, ship or any other that arrive at the Culata and Gulf of Urabá, which is in this governorate, that because with the caciques peace and amity are beginning to settle, that none be reckless to do them wrong or injury, nor take anything from them against their will ... under penalty of death and the loss of all his property.

FRIEDE, doc. 393,296

Julián Gutiérrez embarked on at least three voyages, always accompanied by the translator, Isabel, who became his wife in 1533. The first voyage is cited in the letter of licenciado Espinosa, which seemed to have been an initiative of Gutiérrez ${ }^{5}$ himself. It resulted in such a success that once the facts were known, Espinosa and governor De la Gama "thought that this rescate should be preserved, and that it should not be done by hands other than the ones of this steward" (Friede, doc. 392, 286). The second voyage started on August 29, 1532 and is perfectly documented and described by the scribe and overseer Fernando Gallego. Gutiérrez arrived in a place "at the mouth of the Urabá river, where said caciques are"(Friede, doc. 396, 299), which could have been the southernmost mouth of the Atrato (known in eighteenth-century maps as the mouth of Urabá), a place somewhere further south, or even on the eastern coast of the gulf, on the cape of Urabá, near where San Sebastián de Urabá was founded. There he found 14 caciques, three of them "from the great river of Dabaive." Everyone, apparently, spoke the same language since the translator was always Isabel and they refer to their leaders and heads with the words tiba and saco, which are words in the Cueva language. This is an interesting issue, especially if the place for meetings was the east coast of the Gulf, because Gutiérrez said at some point: "I came to the culata and gulf of Urabá, until the hill of the águila, to pacify the principal caciques and indios of such coast and gulf" (Friede, doc. 396, 312). This part of the Gulf, far beyond the limits of the governorate of Panamá, ${ }^{6}$ was theoretically

5 As can be inferred from the words of Espinosa, and even more so from those of governor De la Gama to the King: "[...] and if you think that good will be done by the hand of said Julián Gutiérrez, as it was he who began it."

6 The motivations of this policy of peace seem to become clearer. In these months Pedro de Heredia was discovering the famous tombs of the Zenú, some leagues from the eastern shore of the Gulf of Urabá, that would fill the personal coffers of Heredia and those of the nascent governorate of Cartagena with gold. The governor of Panamá was evidently overcoming the boundary between the two governorates with a clear objective, since in July of 1535 he pretended that Pedro de Heredia and his people "leave from the said provinces of the Cenú and from all the others that are and belong to this governorate" (Friede, doc. 752, 303). The final objective was the gold of Zenú that clearly pertained as a region to Cartagena. 
inhabited by different peoples - the so-called hurabaes, archers that must have been linked to the Zenú people. But according to the accounts of Julián Gutiérrez' voyages, it appears that they understood each other and were related ${ }^{7}$ to an indigenous woman from the family of the cacique Corobarí, on the other side of the Gulf, that must have spoken the Cueva language.

Another interesting fact is the exchange between the Spaniards and indigenous peoples, who by then already had a good understanding of the Europeans and their goods. Gutiérrez donated gifts such as knives, combs, needles, hooks, and certain shirts from Holland with their "deep red hoods plastered with blue velvet." The caciques, however, only wanted axes and iron knives, which they surely appreciated for their productive efficiency. On his second voyage, Gutiérrez sold about two hundred items consisting of axes and iron daggers in exchange for gold.

During the third voyage of Julián Gutiérrez, from September to October 1532, something particularly interesting happened. On his trip to the town of the cacique Everaba, the brigantine of Gutiérrez made a stop "at the port of Darién," where the indigenous peoples and some Spaniards traveling with him decided to go "to the town of Darién" in order to fish and hunt iguanas. Here they found "some tracks of negros" (Friede, doc. 401, 334). Seven years after its abandonment, the port and city of Santa María continued to be a geographical point of reference. On his way back, Gutiérrez stopped again in the port of Darién, accompanied by the cacique Everaba and 26 natives from his group, determined to kill the cimarrones (maroons).

We arrived at the said port Friday afternoon. Another day after eating we went upriver from Darién by the toldo [warehouse], and others upriver, and went to where the town used to be ... and said Julián Gutiérrez went in pursuit and I went with him upriver one league, following the track of two or three negros. ... and we followed the track until night came and there said Julián Gutiérrez stopped. ... and after a while said indios returned to where said Julián Gutiérrez was and his companions to let them know how said Gonzalo had encountered a hut and in it there were some certain negros roasting meat over a fire ... and said Julián Gutiérrez asked said Gonzalo if with the negros he had seen any indios, and said Gonzalo said no, only the negros who were singing. ... And we stopped there until they fell asleep. ... And then said Julián

7 One of her sisters was the wife of the principal cacique of the area, Everaba, sometimes known as Hurava, and the other was the wife of the son of said cacique. 
Gutiérrez set off with his companions upriver, and the cacique with his indios through the thick vegetation, and when we arrived we encountered them. And said cacique and indios were frightened by them and we were left alone with said negros, and said cacique Everaba shot a poisoned arrow at one who was fleeing, hitting him in the side and said negro fell in the river. And since nobody went to him, since the indios did not dare to, said negro got up and left so that of the three negros we caught one and the other two escaped, one poisoned and the other with many cuts, and I think none would have escaped [far] and we gave them for dead.

FRIEDE, doc. 401, 340-341

This excerpt was narrated by the scribe and observer Gil de Morales, who accompanied Gutiérrez on this third voyage. It contains some interesting information. First, the two ways of reaching the place where the city was located are described. The first one was a trail that evidently began where "the toldo" was, that is the construction that functioned as a warehouse on the coast. The second, going up the Darién River, was longer. Once they arrived at the site of Santa María, the group followed "the tracks of two or three negros," a small group of cimarrones, one league (5/5.5 km) upriver. According to the way Gutiérrez reacts to the news of the cimarrones, this does not seem to be a novelty to him. It would be interesting to know what these "tracks of negros" were, immediately recognizable as those of fugitive slaves, perhaps the remains of a campsite or the ash of hearths. Anyway, it is obvious that at the site where Santa María de la Antigua del Darién had been, there was no stable indigenous presence any longer. The presence of a small group of African fugitives that settled here in "a hut," probably in a transitory fashion, is interesting because it represents a very early occurrence and bears witness to a phenomenon that was probably much more widespread in a territory abandoned by the Spanish which was very difficult to control. We cannot speak of a palenque, but the image of a palisaded hamlet in which a group of Africans cooked meat and sang their songs is very evocative and attests to early, albeit ephemeral, settlements.

The fear of the natives when faced with the Africans is interesting: none of them, and they are 26 against 3 , managed to get close to them. Although this would seem to attest to very few contacts between these two ethnic groups, Gutiérrez' question to his second translator Gonzalo that "if with the negros he had seen any indios" makes one think that the reception of such fugitives by indigenous groups must not have been rare. 


\section{Conclusions}

Attempting to reconstruct the common life and social relations that took place at Santa María de la Antigua del Darién also means trying to reconstruct the layout of the city and the dynamics which developed here, where there have not remained any visible structures, plans, or clear descriptions. We are still at the beginning of this journey, but we can already place the city next to the Darién River, see it leaning out in front of one of the branches, and being bisected by another one. Comparing the data from documentary sources to those from the field investigations, we have been able to understand something about the relation between solares and houses. Furthermore, the stratigraphic excavations clearly demonstrate that indigenous servants were not relegated to the outskirts of the city, but lived in small wooden houses next to Spanish properties. The discovery of a fragment of indigenous-made pottery with European motifs in the midden of one of these houses is proof of very strong dynamics of cultural syncretism, in both directions. Not only did the Spanish apply indigenous techniques and materials in the construction of their houses and made daily use of local ceramics (Sarcina 2017), also the indigenous peoples adopted European motifs for decorating some of their vessels. Likewise, the indigenous peoples quickly began to appreciate metal objects, especially those made of iron, which were more efficient than lithic tools, as we can infer from the travel accounts of Julián Gutiérrez.

The dramatic ending of the city of Santa María de la Antigua del Darién, as recorded by historians, seems to be confirmed by the archaeological data from the stratigraphic excavations of 2015 and 2016 (Sarcina 2016, 2018). After its abandonment, it seems the city area was never permanently occupied again, but only frequented by indigenous groups with ritual purposes, possibly of "cleansing," by placing offerings of small ceramic pieces or worked stone items (Sarcina 2014, 2016). This same area was also frequented during the immediate years following the abandonment of the city by small groups of fugitive African slaves that set up temporary camps, at least in one case reported in the travel accounts of Julián Gutiérrez.

Santa María de la Antigua del Darién is the "missing link" in the history of early urban planning in the colonial Americas, filling an empty temporal space between Santo Domingo and Panama. Its study is a fundamental step to understand how the strategies of Spanish colonization, through the founding of cities, evolved and transformed with the passage of time and with increased control of territory. The results of archaeological research (with stratigraphic and geophysical methods and the study of soils, plant remains, etc.) compared 
to the study of primary sources and the plans of other contemporary Spanish cities already offer a glimpse into how real needs, geomorphology, and the relationship with local indigenous populations determined, in this first continental settlement, a city layout that was very distant from the Renaissance ideal derived from the original Greek-Roman model.

\section{Acknowledgments}

I want to thank the Colombian Institute of Anthropology and History (ICANH) and the Ministry of Culture of Colombia for having promoted and supported the research in Santa María de la Antigua from 2013 until today. In particular, I would like to thank the director of ICANH, Ernesto Montenegro, for his constant support. I also wish to thank Corinne Hofman and Floris Keehnen for inviting me to the symposium "Material Encounters and Indigenous Transformations in the Early Colonial Americas," held during the SAA 82nd Annual Meeting in Vancouver, which forms the basis of this volume.

\section{References}

Andagoya, Pascual de. 1986. Relación y Documentos. Crónicas de América. Madrid: Edición de Adrián Blázquez, Historia 16.

Anglería, Pedro Mártir de. 1989. Decadas del nuevo mundo. Madrid: Ediciones Polifemo. Aprile-Gniset, Jacques. 1991. La Ciudad Colombiana. Prehispanica, de conquista e indiana, Vol. ı. Bogotá: Banco Popular.

Friede, Juan, ed. 1955-196o. Documentos inéditos para la historia de Colombia, Vol. 1. Bogotá: Academia Colombiana de Historia.

Grupo de Memoria Histórica. 2013. iBasta ya!. Colombia: Memorias de guerra y dignidad. Bogotá: Imprenta Nacional.

Oviedo y Valdés, Gonzalo Fernández de. [1851-1855] 1535. Historia general y natural de las Indias, islas y tierra firme del mar Océano, 4 vols. Madrid: Imprenta de la Real Academia de la Historia.

Rivera, Javier. 2014. En Plan Especial de Manejo y Protección Santa María de la Antigua del Darién, Inédito. Bogotá: ICANH y Ministerio de Cultura de Colombia.

Sarcina, Alberto. 2014. "En Plan Especial de Manejo y Protección Santa María de la Antigua del Darién." Unpublished report. Bogotá: ICANH y Ministerio de Cultura de Colombia. 
Sarcina, Alberto. 2015. "Santa María de la Antigua del Darién. Misión arqueológica 2015. Final report.” Unpublished report. Bogotá: ICANH.

Sarcina, Alberto. 2016. "Santa María de la Antigua del Darién. Misión 2016. Final report." Unpublished report. Bogotá: ICANH.

Sarcina, Alberto. 2017. "Santa María de la Antigua del Darién, la primera ciudad española en Tierra Firme: una prospección arqueológica sistemática." Revista Colombiana de Antropología. 53(1): 269-300.

Sarcina, Alberto. 2018. "Santa María de la Antigua y Darién. Los dos caras de la primera ciudad europea en tierra firme." INDIANA. 35(2): 243-269.

Serrano y Sanz, Manuel D. 1918. Origenes de la dominación española en América, Vol. 1. Madrid: Casa Editorial Bailly Bailliere.

Tejeira Davis, Eduardo. 1996. "Pedrarias Dávila y sus fundaciones en Tierra Firme, 15131522." In Anales del Instituto de Investigaciones Estéticas Vol XVIII, 41-77. Mexico City: National Autonomous University of Mexico. 